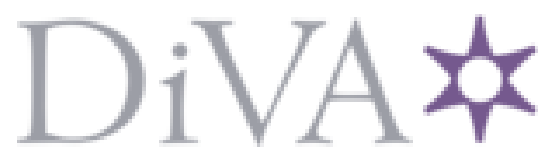

http://www.diva-portal.org

\title{
Postprint
}

This is the accepted version of a paper published in Journal of Service Management. This paper has been peer-reviewed but does not include the final publisher proof-corrections or journal pagination.

Citation for the original published paper (version of record):

Witell, L., Kristensson, P., Gustafsson, A., Löfgren, M. (2011)

Idea Generation: Customer Co-creation versus Traditional Market Research Techniques.

Journal of Service Management, 22(2): 140-159

Access to the published version may require subscription.

N.B. When citing this work, cite the original published paper.

Permanent link to this version:

http://urn.kb.se/resolve?urn=urn:nbn:se:kau:diva-11479 
Idea Generation: Customer Co-creation versus Traditional Market Research Techniques

\author{
LARS WITELL ${ }^{1,2}$, PER KRISTENSSON ${ }^{1}$, ANDERS GUSTAFSSON $^{1}$, \& MARTIN \\ LÖFGREN $^{1}$ \\ ${ }^{1}$ CTF - Service Research Center, Karlstad University, SE-651 88 Karlstad, Sweden \\ ${ }^{2}$ Industrial Engineering and Management, Linköping University, SE-581 83 Linköping, \\ Sweden
}

Associate Professor Lars Witell can be reached at Lars.Witell@kau.se Associate Professor Per Kristensson can be reached at Per.Kristensson@kau.se Professor Anders Gustafsson can be reached at Anders.Gustafsson@kau.se Assistant Professor Martin Löfgren can be reached at Martin.Lofgren@kau.se 


\section{Short biographies:}

Lars Witell is associate professor in the CTF - Service Research Center at Karlstad University, Sweden. Dr. Witell researches product and service development, customer orientation, and service infusion in manufacturing. He has written approximately 30 book chapters and papers in scientific journals.

Per Kristensson is associate professor in the CTF - Service Research Center at Karlstad University, Sweden. His main research interests concern co-creation and, more specifically, the conditions within which users are able to contribute creative ideas to instigate service development. Dr. Kristensson has published a variety of articles on topics such as service development, consumer behavior, and creativity.

Anders Gustafsson is professor of business administration in the CTF - Service Research Center at Karlstad University, Sweden. Dr. Gustafsson is the author of nine books, including: Competing in a Service Economy: How to Create a Competitive Advantage through Service Development and Innovation (Jossey-Bass, 2003), Improving Customer Satisfaction, Loyalty and Profit: An Integrated Measurement and Management System (Jossey-Bass, 2000), and Conjoint Measurement - Methods and Applications (Springer, $20033^{\text {rd }}$ edition). Dr. Gustafsson has also published over 100 academic articles, book chapters and industry reports.

Martin Löfgren is assistant professor in business administration in the CTF - Service Research Center at Karlstad University, Sweden. His current research projects focus on customer satisfaction, Kano's theory of attractive quality, and packaging contributing to improve customer perceived value. His research has been published in Managing Service Quality, Quality Management Journal, Journal of Product \& Brand Management, and Journal of Cleaner Production. 
Idea Generation: Customer Co-creation versus Traditional Market Research Techniques

\author{
LARS WITELL $^{1,2}$, PER KRISTENSSON ${ }^{1}$, ANDERS GUSTAFSSON $^{1}$, \& MARTIN \\ LÖFGREN $^{1}$ \\ ${ }^{1}$ CTF - Service Research Center, Karlstad University, SE-651 88 Karlstad, Sweden \\ ${ }^{2}$ Industrial Engineering and Management, Linköping University, SE-581 83 Linköping, \\ Sweden
}

Associate Professor Lars Witell can be reached at Lars.Witell@kau.se Associate Professor Per Kristensson can be reached at Per.Kristensson@kau.se

Professor Anders Gustafsson can be reached at Anders.Gustafsson@kau.se Assistant Professor Martin Löfgren can be reached at Martin.Lofgren@kau.se 


\section{Idea Generation: Co-creation versus Traditional Market Research Techniques}

\section{Short biographies:}

Lars Witell is associate professor in the CTF (Service Research Center) at Karlstad University, Sweden. Dr. Witell researches product and service development, customer orientation, and service infusion in manufacturing. He has written approximately 30 book chapters and papers in scientific journals.

Per Kristensson is associate professor in the CTF (Service Research Center) at Karlstad University, Sweden. His main research interests concern co-creation and, more specifically, the conditions within which users are able to contribute creative ideas to instigate service development. Dr. Kristensson has published a variety of articles on topics such as service development, consumer behavior, and creativity.

Anders Gustafsson is professor of business administration in the CTF (Service Research Center) at Karlstad University, Sweden. Dr. Gustafsson is the author of nine books, including: Competing in a Service Economy: How to Create a Competitive Advantage through Service Development and Innovation (Jossey-Bass, 2003), Improving Customer Satisfaction, Loyalty and Profit: An Integrated Measurement and Management System (Jossey-Bass, 2000), and Conjoint Measurement - Methods and Applications (Springer, 2003 $3^{\text {rd }}$ edition). Dr. Gustafsson has also published over 100 academic articles, book chapters, and industry reports.

Martin Löfgren is assistant professor of business administration in the CTF (Service Research Center) at Karlstad University, Sweden. His current research projects focus on customer satisfaction, Kano's theory of attractive quality, and packaging contributing to improve customer perceived value. His research has been published in Managing Service Quality, Quality Management Journal, Journal of Product \& Brand Management, and Journal of Cleaner Production. 


\title{
Idea Generation: Customer Co-creation versus Traditional Market Research Techniques
}

\begin{abstract}
Purpose: The purpose of this research is to understand the differences between proactive and reactive market research techniques during the development of new market offerings. The study focused on the financial and innovative performance of traditional market research techniques, such as focus groups and in-depth interviews, in comparison to more co-creationoriented techniques that are designed to capture customers' value-in-use.

Design/methodology/approach: The study was a two-stage process. Study I, an empirical investigation of 195 development projects in European companies, examined how these companies use different market research techniques and how this relates to the profit margins of new products and services. Study II designed an experiment with 50 users of a consumer good and evaluated the contribution of different market research techniques, based on the degree of originality and customer value.
\end{abstract}

Findings: Significant differences were found, in terms of both content and originality, between the technique based on customer co-creation and the two traditional market research techniques (Study II). These findings can help explain why the relationship between the use of market research techniques and profit margin (Study I) is stronger for co-creation techniques than it is for traditional market research techniques.

Originality/value: Despite empirical evidence that the application of market research techniques based on co-creation can lead to original ideas, there is a lack of valid studies regarding how co-creation techniques perform in relation to more traditional methods of collaboration with customers.

Category: Research paper

Keywords: Co-creation, service innovation, service logic, creative performance 


\section{INTRODUCTION}

From the service-dominant logic perspective, a market offering is attractive if it captures its value-in-use (Vargo and Lusch, 2004). The true value of a market offering can only be evaluated through the lens of the customer. The focus is not on the market offering, per se, but on the customers' value creation processes, in which value for customers emerges (Grönroos, 2000; Moeller, 2008). These processes should be the point of departure when conducting market research, yet the literature remains preoccupied with decision-making, focusing on what customers purchase rather than what they actually do (Xie et al., 2007). Contemporary marketing research seems to be based on an artificial separation of production and consumption (Xie et al., 2007; Firat and Venkatesh, 1995), and customers are often viewed as passive responders to various market offerings rather than active participants in the value-creation process. This article argues that replacing the passive view of customers with an active view, in which customers are invited to use their own initiative rather than simply react to predetermined questions and instructions, will provide new opportunities for companies to create market offerings with greater customer value.

According to the literature, the difference between a passive customer and an active one depends on whether a firm embraces a responsive or a proactive market orientation (Narver et al., 2004). Responsive market orientation ${ }^{1}$ concerns a firm's attempts to discover, understand and satisfy the expressed needs of its customers. Proactive market orientation, on the other hand, has been described as a 'customer-driven' process in which the firm must discover, understand, and satisfy the latent needs of its customers or discover new market opportunities. This can be accomplished by working closely with lead users or by conducting market experiments to discover future needs (Jaworski et al., 2000; Slater and Narver, 1998;

\footnotetext{
${ }^{1}$ Responsive market orientation is also referred to as 'customer-led' (Slater and Narver, 1998) and 'customercompelled' (Day, 1999).
} 
Atuahene-Gima et al., 2005; Narver et al., 2004). While previous research has focused on responsive market orientation (Jaworski et al., 2000; Slater and Narver, 1995), the present study has focused on demystifying the role of proactive market orientation and some of the market research techniques connected to the notion of the active customer (Prahalad and Ramaswamy, 2000).

Some of the more common market research techniques that companies use to generate customer information include surveys, in-depth interviews, and focus groups (Verma et al., 2008). These techniques, which concentrate on capturing customers' previous experiences with a product or service, have been designed so that the participants respond to stimuli from the company. Accordingly, these market research techniques have been categorized as reactive or backward-looking (Johnson, 1998). Companies that employ these techniques either decide what type of questions should be asked (for example, in a survey) or they limit responses by, for example, asking about a consumer's previous experience with a service or the usability of a new service. This limits the opportunity to provide new insights and thoughts that lie outside the prepared interview guide or questionnaire. In such cases, customers are likely to base their responses on their experiences with previous usage, which is not really suitable when predicting future usage (Trott, 2001). In contrast, forward-looking techniques assist in the development of innovative new services that build on gaining greater access to customers' underlying values and behaviors (Johnson, 1998). According to Johnson (1998), the main difference between proactive and reactive methods is that reactive methods capture consumers' spoken needs, while proactive methods seek to capture a wider range of information, in the form of both spoken needs and unspoken - or so-called latent - needs. The distinction between the spoken needs captured by the above mentioned methods and latent needs can also be found in Narver et al. (2004). Gustafsson et al. (1999) and Lilja and 
Wiklund (2007) argue that methods such as in-depth interviews and focus groups are able to capture spoken needs, but that there are better methods for capturing unspoken latent needs.

The lead user method is a market research technique that is frequently cited as being proactive (von Hippel, 1986) because the user is actively engaged in creative problemsolving at the location where needs are present. This increases the likelihood that latent needs will be taken into account when suggesting a new solution. In contrast, a typical characteristic of reactive market research is that the role of the customer, “...is essentially that of respondent, speaking only when spoken to" (von Hippel, 1978, p. 40). The present article argues that market research techniques that give customers greater leeway to take the initiative and make their own discoveries, and in which value is co-created with the customer, are more likely to contribute to the success of new development projects. It should be noted, however, that the application of a certain market research technique does not, in and of itself, lead to commercial success. The degree of market orientation within a firm is likely to influence whether a market technique will help the firm discover new ideas and implement these ideas in new services (Narver et al., 2004).

The purpose of this research is to understand the differences between proactive and reactive market research techniques when developing new market offerings. The empirical investigation focuses on how the performance of traditional market research techniques, such as focus groups and in-depth interviews, compares to more co-creation-oriented techniques designed to capture customers' value-in-use. The article argues that market offerings that are developed with a market research technique that allows customers to focus on their own value-in-use are more likely to provide ideas that are beneficial for service innovation. The research was conducted within a two-stage research study that compared various market research techniques on two different levels. The first step was to investigate how the two different kinds of market research techniques contributed to the profit margins of newly 
developed products and services. Study I is an empirical investigation of 195 development projects in European companies. It examines how these companies use different market research techniques and how their usage is related to the profit margins of new products and services. The second step investigated the content of the contribution using three different market research techniques in order to study their relationship with originality and customer value. In Study II, an experiment was designed with 50 users of a consumer good and evaluated the contribution of various market research techniques based on the degree of originality and customer value. The results of these two studies make several contributions to the existing literature. They show that market research techniques affect a project's success in a number of ways and that the content of the output varies depending on the role of the customer in the development project. Given the importance of market research, the results indicate that a more deliberate approach should be taken to selecting market research techniques; in other words, the various methods have different strengths and weaknesses.

\section{The Concepts of Co-creation and Prosumption}

Most contributions in marketing have been consistent with the goods-dominant logic view of customers as passive buyers of what others produce (Xie et al., 2007). Unlike a goods-dominant logic view, which starts with an existing market offering, a service-dominant logic view begins with an understanding of the customer's problem and identifies products and services that can solve these problems (Sawhney, 2006). Value-in-use is a central theme for the service-dominant logic because the customer is always a co-creator of value (Vargo and Lusch 2004; Lusch and Vargo, 2006). Value-in-use (i) implies that value is determined by and can only be created with the customer in the consumption process through use, and (ii) involves customer participation in the creation of the core market offering itself. Value- 
in-use can occur through shared inventiveness, co-design, or the shared production of related goods, with customers and with any other partners in the value network.

In order for companies to meet the demands of mass communication, they must engage in an interactive dialog with customers. The process a company must tap into in order to really understand their customers is sometimes referred to as prosumption (Toffler, 1980). Prosumption is a process in which consumers co-design and co-produce their own products and services. Such processes blur the distinction between consumers and producers, which makes the 'quality of the consumer' as, if not more important than the quality of the service provider (Toffler, 1980). The acceptance of prosumption as a phenomenon implies that, rather than simply being passive constituents of an industry, customers become principal participants in the creation of and competition for value (Prahalad and Ramaswamy, 2000).

Based on Xie et al., (2007), prosumption is defined as value creation activities undertaken by customers that result in the production of products they eventually consume and that become their consumption experience. The activities needed in service production include manufacturing-related activities such as procuring, assorting, moving, combining and changing inputs (Xie et al., 2007). The concept of prosumption has similarities with the latest development of service-dominant logic and the concept of value-in-context (Vargo, 2008). Each customer is considered to be its own primary resource integrator, applying its uniquely configured skills and resources. Humphreys and Grayson (2008) argued the need to make a distinction between co-creation for use and co-creation for value-exchange (referred to hereafter as co-creation for others). The two processes differ in their orientation: co-creation for use is performed by a specific customer for his or her own benefit, while co-creation for others is oriented towards other customers. While the aim of co-creation for use is to enjoy the production process and its outcome, co-creation for others aims to provide an idea, share 
knowledge, or participate in the development of a product or service that can be of value for other customers.

\section{Co-creation for others}

Lusch et al., (2007) argued that an organization requires absorptive competence in order to renew its value propositions or offered services. In other words, it must be able to comprehend important external trends and knowledge. This article argues that the customer has an important role to play in this process and that an organization must develop its collaborative competence in order to move away from perceiving the customer as a source of information, and towards treating the customer as an active contributor with knowledge and skills.

The potential of customers as active contributors in the development of new products or services has long been recognized (e.g., Gardiner and Rothwell, 1985; Leonard-Barton, 1995; Rothwell, 1976; von Hippel, 1988). The phenomenon of customer co-creation relates to a wide number of concepts, including the lead user method (von Hippel, 1986), codevelopment (Anderson and Crocca, 1993; Neale and Corkindale, 1998), co-opting customer competence (Prahalad and Ramaswamy, 2000), user involvement (Alam, 2002; Kristensson et al., 2004), consumer involvement (Pitta et al., 1996), and customer interaction (Gruner and Homburg, 2000). In keeping with most of the existing empirical research and with available anecdotal accounts, co-creation for others is defined here as activities in which customers actively participate in the early phases of the development process by contributing information about their own needs and/or suggesting ideas for future services that they would value being able to use. However, despite the rhetoric related to customer or user ${ }^{2}$ co-creation in the development process of new products and services, customers seem to have played a

\footnotetext{
${ }^{2}$ In this paper, the terms 'user' and 'customer' are used interchangeably. The most appropriate term usually depends on the type of market in question.
} 
limited and largely passive role in most industries (Nambisan, 2002). This leads to a shift away from the traditional method of involving passive customers during the latter phase of prototype testing towards viewing them as active participants for co-creation during the ideation phase.

\section{Study design}

This study incorporated a two-stage empirical investigation into the effects of market research techniques that allow customers to be active or passive, to varying degrees, in the development process. This process is presented in the following sections as Study I and Study II. Based on the literature review, the article investigates the effect that proactive and reactive market research techniques have on profit margins from new products and services (Study I) and on idea generation (Study II). Study I aimed to show that the use of proactive or reactive market research techniques have different effects, while Study II explains why the effects are different.

\section{Study I: The financial value of co-creation}

In line with Lilien et al. (2002), Study I worked on the premise that investigating the financial value of using passive versus active customers in market research was in the interests of both practitioners and managers. The study was designed to measure the degree to which certain market research techniques were used in the development process and to relate these measures to the profits of new products and services. For Study I, financial data was gathered from companies regarding products and services that they had recently launched. The main role of Study I was to illustrate the differences between the results of development projects in which customers had either passive or active roles in market research during the development of a new product or service. 


\section{Hypotheses}

From a service-dominant logic perspective, customers are always co-creators of value (Vargo and Lusch, 2004) and act as resource integrators (Lusch and Vargo, 2006) during consumption. As a consequence, an active customer could be a resource in the development process, providing competence and skills that may not exist in a traditional development team (Kristensson et al., 2004). Changing the role of a customer from passive to active during the development process provides an organization with an important external resource - the customer (Prahalad and Ramaswamy, 2000). With reactive market research techniques, customers provide the organization with information resulting from direct questions and instructions; the organization's employees then process this information and use it for development. In some phases of the development process this is very useful information. However, these methods require substantial financial resources (Griffin and Hauser, 1993) and employees often lack the skills related to value-in-use for customers (Gustafsson and Johnson, 2003). As a result, the firm ends up focusing on its current knowledge and gaining an in-depth understanding of its current customers and their expressed needs (Baker and Sinkula, 1999; Berthon et al., 1999; Atuahene-Gima et al., 2005; Narver et al., 2004). This can have a positive influence on new product and service development performance by turning the company's focus towards working on the expressed needs of current customers. Johnson (1998) argued that reactive methods have elicited volumes of data on performance attributes (product and service attributes for which incremental improvements are appreciated) but only provide limited insight into the unexpected or 'excitement' attributes that surprise and delight customers. Furthermore, one of the main problems with reactive methods is that they focus on understanding the customer's perception of existing concrete attributes rather than their value-serving benefits (Johnson, 1998). 
With a proactive market research technique such as the lead-user method, customers provide an organization with information that has been already processed by resources (that is, customers) that have a stronger set of skills related to value-in-use. By including knowledge from the context of use, a future market offering that is being developed is more likely to yield satisfied customers, since proactive research techniques capture a wider range of customer information (Johnson, 1998). This paper argues that market offerings developed with a strong focus on future use are more likely to generate products and services that create a new category of market offerings. In other words, market offerings developed on the basis of use information provided by active customers during market research will result in future innovations that have fewer competitors and are, therefore, more profitable for companies. From an organizational perspective, active market research techniques reflect exploratory learning behavior that involves searching for new and diverse information, as well as for knowledge that can lead a firm beyond its existing experiences (March, 1991). A focus on the latent needs of both extant and potential customers can result in variation in organizational activities. In such cases, firms usually possess strong means for adding new variants of demand information for all kinds of customers in the early phases of the development process, which increases their ability to design and deliver solutions to customers (Levinthal and March, 1993; March, 1991; Atuahene-Gima et al., 2005; Narver et al., 2004). Based on the above, Hypothesis 1 is as follows:

\section{Hypothesis 1: Proactive market research techniques (in which customers take initiative) have a greater influence on the profits of new products and services than reactive market research techniques (in which customers react to information).}

In order to test this hypothesis, an empirical investigation was designed to focus on the use of two specific market research techniques (customer interviews and the lead user method) in selected European development projects. 


\section{Sample}

E-mail surveys were sent to the R\&D and marketing managers of European firms selected from an externally purchased database. It was not possible to screen firms in advance to determine which firms had a development organization. Accordingly, managers were asked to participate only if they worked in an organization that conducted development projects and if these development projects used different market research techniques to some extent.

Reminders were mailed to non-respondents one and two weeks after the initial mailing, which yielded a response rate of 15 percent (195 respondents). This was used in addition to objective financial data found in an existing open database in which publicly listed companies are required to report key performance indicators. Telephone interviews were conducted with 100 managers from firms that did not respond, with the purpose of determining how many of the firms in the sample conducted development projects. Thirtyseven of these 100 managers indicated that their company did not conduct any development projects. Following the procedure recommended by Armstrong and Overton (1977), the tests indicated that there were no statistically significant differences between early and late respondents in terms of the survey data or the objective financial measures.

Complete data was obtained for manufacturing and service firms in industries such as wood, pulp and paper, chemicals, plastic goods, fabricated metal goods, machinery and equipment, electrical and optical equipment, construction, real estate, construction services, and business services (see Table 1). The most strongly represented industries were construction services (20 percent), machinery and equipment (14 percent), fabricated metal goods (13 percent), and wood, pulp and paper (11 percent). Firms in the sample had an average of 270 employees, average turnover of 28 million Euros, and an average profit margin of 3.5 percent. 
- Insert Table 1 about here -

\section{Measures and Descriptive Statistics}

The study measured the use of the two market research techniques - customer interviews and the lead user approach - on an overall level regarding the share of development projects in which these market research techniques were used. Most items received a rating on a ten-point Likert scale, ranging from 0 percent of the projects (1) to 100 percent (10). This level of detail was chosen because it is at the same level of detail as the share of profits that come from new products and services on the market.

Business performance was based on the firm's overall profit margin over a two-year period, rather than on profits generated by the individual product or service. Profit margin accounts for both the increased sales of new products and services and the costs associated with their development. The standard accounting measure of profit margin was used, calculated as net sales less the cost of products and services sold and selling and administrative expenses (before deducting depreciation). This paper argues that firms that use the intended market research techniques in the development process are likely to experience increased project success, which will contribute to the company's profits. Using previous profit margin as a control variable provides an estimate of the share of the profit margin that comes from new products and services (see, e.g., Cooper, 1993).

\section{Control Variables}

Several other factors, such as the firm's previous profit margins, industry and company size, were also measured in order to identify the effects that various market research techniques have on profit margins. Firstly, industry was controlled for as a fixed factor because the level of profit margin and the use of market research techniques vary across industries. Specifically, all firms were divided into groups according to their SIC industry 
codes, and all items used to measure the use of different market research techniques and profit margins were then mean-centered.

Secondly, the study controlled for firm size, which has previously been shown to influence product development activities (Narver and Slater, 1990) and can also indicate the level of a firm's resources (Rust et al., 2002). The number of employees at each firm was collected from an external database.

Thirdly, a lagged measure of profit margin was included in order to isolate the recent effects that various market research techniques have on profit margin. This covariate serves two other useful purposes. One, a company that has been profitable in the past is more likely to be profitable in the future, and two, the use of previous profit margins serves as a control for industry-specific factors that influence the profit margin of firms in different industries. Results

A general linear model $(n=195)$ was estimated in order to test how the use of various market research techniques influences the profit margin from new services. The dependent variable was profit margin, while the independent variables included the use of customer interviews and the lead user method. Previous profit margin and firm size were used as control variables.

The model was estimated for firms $(n=195)$ and the results of the general linear model estimations are shown in Table 2. The different market research techniques account for 13 percent of the variation in profit margin. The results clearly show that using market research techniques in product and service development has an influence on the profits from new products and services. The effect sizes reveal that using the lead user approach $(\beta=0.34$, $\mathrm{p}<0.05$ ) has a positive linear effect, while no such effect is found from the customer interview approach $(\beta=-0,031, \mathrm{p}>0.10)$. These results support Hypothesis 1 , which says that proactive market research techniques (in which customers actively take initiative) influence profit 
margins more strongly than reactive market research techniques (in which customers react to the information they are given).

- Insert Table 2 about here -

The results of Study I show that, at a general level, there seems to be a relationship between the use of proactive market research techniques and profits for new products and services. The results validate the findings of Lilien et al. (2002), which is important because this study employs another research methodology and relies on data from European companies.

One weakness of Study I is that the results of certain market research techniques may be due to poor implementation of the technique rather than the technique itself (e.g., Chai and Xin, 2006). The need for greater understanding of the mechanisms behind this finding is one reason why the second study is necessary. Study II compared the results of three methods through which work practice was adjusted to support the idea generation process. Another weakness of the first study is the substantial time lag between using a market research technique and determining the eventual profit margin for a new product or service. Despite the inclusion of several control variables, there might be additional explanations for the results. In order to overcome this limitation in Study II, the unit of analysis was narrowed from the results of development projects to the output from the market research techniques. In addition, the second study was conducted within the early phases of development projects within one single industry. The design of Study II made it possible to create a stronger test of the hypotheses, in terms of the results of using different market research techniques.

Consequently, this enabled a better understanding of why the results are different.

\section{Study II: The merits of co-creation in comparison with traditional market research techniques}


The results of Study I show that proactive market research techniques make a greater contribution to profit margins than reactive techniques. Study II aimed to investigate the content of the contribution (such as ideas for new features, functions and services) by comparing market research techniques and their relationships to originality and provided customer value. The issue to be tested was how the originality and value of contributions varies between reactive and proactive market research techniques. The empirical context for Study II was the development of ideas for new functions, products and services related to microwave ovens.

\section{Hypotheses}

Psychological research has identified several important cognitive processing commonalities that individuals use when creating ideas. One striking example is the overwhelming role of prior knowledge during creative tasks. According to Perkins (1988), creativity primarily consists of remembering former ideas and reassembling them in a novel way (Marsh et al., 1999a; Marsh et al., 1999b). Ward (1995) expressed a similar view, saying that it is rare for a novel product to be entirely novel, insofar as it possesses features of the ideas or products that were used in the creative combination process. Because participants tend to return to former ideas, perhaps by applying a systematic search among relevant knowledge structures, their 'novel' product ideas tend to be much less innovative than they could have been if they did not call on their prior knowledge. Marsh et al. (1999a) showed that if the goal is to achieve original product ideas, providing examples actually tends to decrease performance.

If, on the other hand, people are instructed to search for situations in which something has happened (for example, a problem or difficulty has occurred, or a certain emotion has been experienced), this can provide the basis for a new idea. According to Kristensson et al. (2004), such cognitive approaches to idea generation are likely to lead to ideas that are 
perceived as being original and/or innovative. The content that stimulates the idea comes from the customer and from a certain situation that can be difficult for a product or service developer to access, understand or foresee, and which may explain the results. Since reactive market research techniques are built on prior knowledge of an existing product or service, such techniques can be expected to provide fewer creative ideas. This leads to Hypothesis 2a:

Hypothesis 2a: The use of a proactive market research technique is more likely to lead to original ideas than a reactive market technique.

Based on prosumption and the service-dominant logic, it is argued that value-in-use can only be created with and determined by the customer during the 'consumption' process. Therefore, companies that aim to develop offerings with high value-in-use should conduct their market research during the process in which value is realized. Market research techniques that are conducted in-situ, or allow the user to use their own initiative when something interesting occurs, are more likely to generate significant knowledge about valuecreation for companies (Kristensson et al., 2004). Companies with active customers in the development process should, therefore, be in a better position to capture real customer value. Proactive market research techniques, such as the lead-user technique or the co-creation techniques used in the present experiment, build on customers that are looking for new ways to create value in their environment. Reactive market research techniques, in contrast, build on the value that has already been designed into the characteristics of an existing product or service. On the basis of these arguments, Hypothesis $2 \mathrm{~b}$ is as follows:

Hypothesis 2b: The use of a proactive market research technique is more likely to lead to ideas of higher customer value than a reactive market technique.

The service-dominant logic (Vargo and Lusch, 2004) states that goods are merely "intermediate products that are used by other operant resources (customers) as appliances in the value creation processes" (p. 7). An idea is assessed on the basis of its value-in-use or the 
resulting consumption experiences. When value is viewed from a service-dominant logic perspective, it follows that an idea for a future offering that is formulated in terms of a service (that is, a description of value creation) has greater value for customers than one based on goods (that is, a description of the technical content and requirements that comprise the good). The reasoning for this is that a service based idea builds on a function or something that a user wants to accomplish by using a product. A service-based idea should have a greater understanding of the customer's problems because it relates directly to the customer's actual use situation. A good, on the other hand, may relate to customer's use situation only if the customer immediately understands how to use it to realize value-in-use. Furthermore, following the tradition of goods-dominant logic, this paper hypothesizes that an idea described as a service (value-in-context) should be perceived as being more original than the same idea described as a product (value proposition). This is because the former is formulated based on an understanding of the customer's actual use situation (which is atypical in the tradition of a goods-dominant logic). When a customer attempts to describe a new idea based on old technology, the idea is not perceived as being as original as it perhaps should be. Customers often do not have a full understanding of the technology so, when the idea is put in the hands of the developers, this will influence their evaluation of the ideas. The old technology has an anchoring effect that causes an idea with lower service content to be perceived as being less original. The same idea described as a service or as a good can be expected to be perceived differently. Accordingly, Hypotheses $3 \mathrm{a}$ and $3 \mathrm{~b}$ can be summarized as follows:

Hypothesis 3a: An idea with a higher degree of service content is considered to have a higher degree of originality than an idea with a lower degree of service content. Hypothesis 3b: An idea with a higher degree of service content is considered to be of higher value than an idea with a lower degree of service content. 
Design

This study used a quasi-experimental design to test the hypotheses. Participants were randomly assigned to three different experimental conditions: in-depth interviews, focus groups and co-creation, which constituted the independent variable of the study. There were 11 customers in the in-depth interview group, 28 in the six focus groups and 11 in the cocreation group. All participants were exposed to written information (a scenario) that informed them of the desire for ideas for new features, functions and services to develop innovative microwave ovens.

\section{Participants}

Fifty individuals (25 men and 25 women) were selected as subjects and randomly assigned to one of three experimental conditions. The individuals' ages ranged from 16 to 45 years, with a mean age of 24. There were no significant (two-way ANOVA) differences among the groups or between genders in terms of age or experience using microwave ovens ( $p>0.05)$. A personality inventory was administered to all participants in order to provide further background information. A one-way ANOVA showed no differences between the groups $(\mathrm{p}>0.05)$ in terms of the consumers' degree of innovativeness, here measured by Price and Ridgeway's (1983) Use Innovativeness Scale.

\section{Measures}

Two panels of scorekeepers were set up in order to obtain measures for the dependent variables. Panels $\mathrm{O}$ and $\mathrm{V}$ judged the merits of the ideas for the three dimensions, which were originality (the newness of an idea, judged by Panel O), user value (the value from a customer's point of view, judged by Panel V), and the number of ideas (how many ideas each 
person provided; no panel was required for this dependent variable). For the focus group condition, several participants often created an idea together (Fern, 1982). In these cases only the final version of the idea was included when operationalizing the variable number of ideas. Each of the panels comprised four judges, all of whom were employed by the microwave oven manufacturer. The panel members each had at least five years of experience in their line of business and decided which development projects the company should initiate.

The panels employed the consensual assessment technique (CAT) introduced by Amabile (1996). In the rating process, the judges used typed service descriptions, which were submitted by the participants and then transformed into an electronic description. Every judge was instructed to rate the ideas on a scale from 1 (lowest) to 10 (highest). The judges rated one dimension at a time and performed the scoring independently and were blind to both the identity of the group participants and to the purpose of the experiment.

\section{Procedure}

Upon arrival at the Consumer Research Laboratory, each participant was assigned randomly to one of three experimental conditions. Participants were told that they were going to participate in a study regarding microwave ovens and that their ideas were of interest for the future development of products and services. They were also informed that the study would serve as a part of a scientific research project and that their contributions were of interest from this perspective as well. Participation was voluntary and all participants were informed of their task approximately two weeks before the actual experiment. This was done to ensure that, regardless of their experimental conditions, all participants had the same amount of time to think about and prepare for their task.

A trained interviewer and moderator conducted the in-depth interviews and the focus groups, and instructed the co-creation group (Fern, 1982). Triggers were introduced during 
all three conditions in order to encourage creativity. These included viewing online microwave cookbooks, baking cakes in the microwave, watching microwave oven chefs on YouTube and making and eating microwave popcorn.

The in-depth interviews and the focus group followed instructions that were typical for these market research techniques (Krueger and Casey, 2000; Kvale and Brinkmann, 2008). The in-depth interviews were one to two hours in duration. The interviewer started all interviews by asking the participants about their microwave oven use and, as the interview proceeded, more questions were directed towards their needs and wishes for the future. Each focus group session had five or six participants and lasted for two hours. The moderator began by asking about present microwave use and then moved the discussion towards needs and wishes for the future. An experienced interviewer and a focus group leader attempted to initiate participants' creativity. Questions and discussion topics included a hypothetical situation in which a person's kitchen burned down and they had to rebuild it again. Participants were asked what the role of the microwave oven would be in such a scenario and what functions and services the offering should include.

Co-creation used ordinary customers (as opposed to lead users) and participants were given the opportunity to take the initiative and share their insights. The co-creation technique procedure was similar to that used in the CuDit experiments (see, e.g., Kristensson et al., 2004). Customers participated in the co-creation group for seven days, during which time they received training in how to use a microwave and were asked to focus on the problems and difficulties they experienced when using their microwaves at home. All participants were provided with a disposable camera with which they could photograph occasions when they encountered specific problems or thought of opportunities while using their microwaves. All ideas and perceived problems were noted in an idea book, which was submitted after the termination of the experiment. 
Results

In accordance with Amabile (1996) and Blackman and Funder (1998), all ratings from judges were averaged. The correlations (Cronbach's alpha) for the judges were $\mathrm{r}=.77$ for Panel $\mathrm{O}$ and r=.58 for Panel V. Overall, the judges' evaluations of originality and value showed significant agreement $(p<.001)$ and were perceived as adequate. As the agreement numbers indicate, it was more difficult to estimate future customer value than to judge what was original.

Table 3 presents the results for originality, value and the number of ideas for the three experimental conditions. An independent t-test showed significant differences in originality between the co-creation condition and the focus group condition $(t=[260] 2.79 ; \mathrm{p}<.05)$ but no difference in comparison with in-depth interviews.

For the development of a real product or service, only the best ideas should be used for further elaboration. Accordingly, a subsequent analysis was conducted using only the top five ideas from each individual. The co-creation condition for this analysis was significantly different than both the in-depth interview condition $(\mathrm{p}<.05)$ and the focus group condition $(\mathrm{p}<.05)$. This confirms Hypothesis $2 \mathrm{a}$. No significant differences were found in terms of value. The same result occurred when all ideas and the top five ideas from each individual were examined, which means that Hypothesis $2 \mathrm{~b}$ must be rejected.

- Insert Table 3 about here -

In order to test Hypotheses $3 \mathrm{a}$ and $3 \mathrm{~b}$, all ideas were judged based on their degree of goods and service using Martin and Horne's (1992) scale, which has scores for (1) pure goods, (2) core goods with accompanying services, (3) core services with accompanying goods, and (4) pure services. One hundred and twenty-five ideas were goods-based (1 and 2) and 38 ideas were service-based ( 3 and 4) (see Table 4). The service-based ideas were 
evaluated as having a higher degree of originality than the goods-based ideas (5.48 compared to $3.69 ; \mathrm{p}<0.01$ ), which supports Hypothesis $3 \mathrm{a}$. In contrast, goods-based ideas were evaluated as having a higher degree of customer value $(6.47$ compared to $5.83 ; \mathrm{p}<0.10)$, which means that Hypothesis $3 \mathrm{~b}$ must be rejected. This additional analysis partly explains the consistency of the results with the service-dominant logic based on an active customer producing more service-based ideas. These ideas are, in turn, evaluated as showing a higher degree of originality but providing less customer value.

- Insert Table 4 about here -

\section{DISCUSSION AND MANAGERIAL IMPLICATIONS}

A large body of scholarly work contends that co-creation has become a critical means for customers to achieve value-in-use. Although this 'collaborative trend' seems well established in the consumption phase through co-creation for use, its consequences are not adequately understood in the service innovation process through co-creation for others. Although some researchers have shown that applying market research techniques based on co-creation can lead to innovative ideas, there is a lack of valid studies regarding how cocreation relates to more traditional methods of collaboration with customers (von Hippel, 2005).

In order to fill this void, the first part of the present study indicates that new market offerings developed through market research techniques based on co-creation are more profitable than those developed through traditional market research techniques. The crosssectional sample revealed that products and services that are developed from ideas derived by active customers through the lead user approach made a significant contribution to the profits of the firm in question. These results are in accordance with those of Lilien et al. (2002), who concluded that the performance of innovations generated by lead users made a greater 
contribution to profits than innovations generated in a more traditional fashion. Because lead users are accustomed to technology and user needs, the lead user method represents one variant of co-creation for others, which strengthens the validity of the study's findings.

Study II identified some of the reasons why co-creation for others makes a greater contribution to profit margin from new products and services than traditional market research techniques. Active customers in the development process produce ideas that are significantly more innovative than those generated through traditional market research techniques. One potential explanation for this involves the location of the idea creation. Participants in the cocreation condition appear to have derived their ideas from an experience that has triggered their understanding of how value-in-context can be created, and they generate ideas about where usage takes place or is assumed to take place. Other techniques that also emphasize the situational aspect of understanding needs are related to ethnographic methods such as contextual inquiry or research in the so-called gemba (Imai, 1997). Customers participating in traditional market research methods, such as focus groups and in-depth interviews, have had to rely on their memories of previous experiences in order to produce ideas (Johnson, 1998). These memories could share some commonalities and represent standard situations of usage, which might explain why the ideas derived from that material were not as innovative (Ward, 1994). Therefore, traditional market research techniques seem restricted by the fact that users have difficulty imagining or remembering scenarios in which they have experienced certain needs (Kristensson, 2006; Trott, 2001). Because cognition is often limited to the situations in which people find themselves at that point in time (Schkade and Kahneman, 1998), focus group participants are likely to be limited to making suggestions connected to that particular moment, or to standard situations that are typically shared by most people. It can be difficult to express latent needs, either because they are difficult to grasp in the absence of a specific need or because they emerge slowly and may not be reflected upon at first. For technology- 
based companies, many new solutions to customer problems are latent in nature because customers may not understand exactly how they could benefit from the technology in the future. Asking users to derive solutions at the same time as they experience needs is likely to improve their understanding of latent needs, which will make their ideas more innovative.

\section{Theoretical Implications}

Co-creation implies a mode in which an organization collaborates with its customers towards a shared goal that, in turn, constitutes one of the foundational premises of the service-dominant logic (Lusch et al., 2007). According to the literature, however, the term 'co-creation' only implies the mutual collaborative efforts that occur during the consumption process, which was the original implication of prosumption. Co-creation commonly excludes the development of the market offering itself, that is, co-creation for others. Similarly, if it occurs during the innovation process, co-creation does not have any implications in terms of how and where customers can share their inventiveness. This paper concurs with several other researchers (Alam, 2002, 2000; Kristensson et al., 2004; Prahalad and Ramaswamy, 2000) that customers should play an important role in the service innovation process.

Organizations must develop their collaborative competence and view customers as active contributors with knowledge and skills rather than simply as sources of information. In order to build on this study, therefore, the following three implications are suggested for customer co-creation for others:

- Co-creation is extended to include activities during the innovation process (co-creation for others) as well as those during consumption (co-creation for use)

- Co-creation for others implies that customers act as idea creators

- Co-creation for others implies that customers act as detectors of value-in-context. 
Firstly, the point of origin is that customers should assume the role of co-developer during the early phases of the service innovation process. As the design of the experiment in Study II shows, such a role enables customers to suggest the types of ideas that the company should develop, and may even help in the design of an early prototype. Activating customers in the co-creation of a good or service can qualitatively enhance the resulting value-in-use; the customer does not only have a say in what service should be delivered but they are also able to tailor it to their needs. Co-creation for others is used here in a qualitatively different way than traditional customization, with the difference lying in the degree to which the customer is activated, which is generally greater in co-creation than it is in customization. The concept of co-creation should, therefore, be extended to encompass activities during the innovation process; such an extension implies a more proactive, market-oriented approach than customization. Consequently, the first theoretical implication concerns an extended view of co-creation that includes the innovation process, rather than just usage.

The second implication is concerned with customers as idea creators. The main claimed benefit of co-creation for others involves the possibility of developing a differentiated new service with unique benefits and enhanced value propositions for potential users (Alam, 2002). This potential is untapped when using reactive market research techniques, which generally takes place on the company's terms rather than in the customer's own environment. Proactive market research techniques such as the lead-user method give customers more say and put them in a better position to contribute with novel ideas. As the results of this study show, co-creation for others in the early phases of the development process can lead to ideas that are more innovative than those that originate from more reactive market research techniques. In addition, previous studies suggest that ordinary users may be better equipped to generate ideas than a company's R\&D employees (e.g., Kristensson et al., 2004). The key is that proactive market research techniques allow users to develop their own needs (value-in- 
context), whereas R\&D employees develop ideas for others (i.e., external users/customers). The results of the present study build on this knowledge and reveal the conditions necessary for customers to produce innovative ideas.

The third implication regards the role of customers as detectors of value-in-context. When innovation is democratized in such a way that customers are encouraged to take the initiative, they will be able to share their inventiveness at locations in which consumption usually takes place. The empirical data in Studies I and II suggests that traditional market research techniques have difficulty transferring latent needs in certain contexts, but are able to express manifest needs. Because latent customer needs are considered to be important in substantiating successful innovation, they therefore represent valuable information. In a typical market research situation, customers answer questions that relate to their past behavior, but at a distance from the situations in which value-in-use is likely to occur (Zaltman, 2003). Furthermore, companies usually possess information about available solutions and search for information related to various requirements. In contrast, considering customers as value co-creating resources implies that they should be provided with solution information that allows them to take the initiative and conduct their own 'need' searches. Unlike traditional market research procedures, a need search is likely to be more effective if customers conduct it in their own setting of use, in which a possible future product or service is expected to play a valuable role. This will allow customers to learn about solutions they can apply in real settings. Ideas are likely to provide critical ingredients for future value-inuse for others if they are derived from customers, because they would take place in locations where customers are likely to co-create value. This is not to say that traditional market research techniques are not useful in many ways, just that the proper tools should be used for the proper purpose. Some customers can be creative and provide useful information 
regardless of the market research technique that is used, while the majority of customers must be involved through co-creation techniques in order to be able to reveal their latent needs.

\section{Managerial Implications}

In-depth interviews and focus groups are valuable tools for certain purposes, but it can sometimes be beneficial to apply other tools. The methods mentioned above maybe suitable for capturing customers' spoken needs, which can be useful for incremental innovations. However, other approaches can be more useful for capturing latent needs and achieving radical innovations (Johnson 1998; Gustafsson and Johnson 2003). The results of the present study show that managers can obtain useful knowledge about customers' value-in-use contexts by involving customers in the early phases of the development process. The basic and crucial point is that customers are the most familiar with their own lives and are therefore the best people to pre-evaluate the value-in-use of products and services. Companies should make greater use of market research techniques that capture customers' ideas derived from real life situations. In other words, co-creation also applies to the innovation phase.

During co-creation for use, customers participate in service production by providing input in the form of money, time, effort, and skills. By procuring, assorting, moving, combining, and changing the inputs provided by a service company, customers are able to generate ideas and prototypes, thereby laying the foundation for a value proposition that can enhance value-in-context for other users; in other words, co-creation for others.

\section{Limitations of the research}

The challenges involved in developing new products and services mean that it is important to have a greater understanding of customer co-creation. However, the present study does have some limitations. Firstly, although the use of objective profit margin as a 
measure of business performance is an improvement on previous research, accounting techniques varies across industries, so future studies should include objective profit margins at the project level. Secondly, the two studies in this paper combine the strengths of crosssectional research and experiments in one organizational context. Nevertheless, in order to confirm this paper's explanations of why different market research techniques have different effects on profits from new products and services, experiments that compare ideas from various market research techniques should be replicated in different empirical contexts using a range of goods and services. 


\section{REFERENCES}

Alam, I. (2002), “An Exploratory Investigation of User Involvement in New Service Development", Journal of the Academy of Marketing Science, Vol. 30 No. 3, pp. 250261.

Amabile, T.M. (1996), Creativity in Context. Westview Press, Boulder, CO.

Anderson, W.L. and Crocca, W.T. (1993), "Engineering practice and codevelopment of product prototypes", Communications of the ACM, Vol. 36 No. 6, pp. 49-56.

Armstrong, J.S. and Overton, T.S. (1977), "Estimating Non-response Bias in Mail Surveys", Journal of Marketing Research, Vol. 14 (August), pp. 396-402.

Atuahene-Gima, K., Stanley, S.F. and Olson, E.M. (2005), “The Contingent Value of Responsive and Proactive Market Orientations for New Product Program Performance”, Journal of Product Innovation Management, Vol. 22 No. 6, pp. 464482.

Baker, W.E. and Sinkula, J.M. (1999), “The Synergistic Effect of Market Orientation and Learning Orientation on Organizational Performance", Journal of the Academy of Marketing Science, Vol. 27 (Fall), pp. 411-427.

Berthon, P., Hulbert, J.M. and Pitt, L.E. (1999), “Brand Management Prognostication”, Sloan Management Review, Vol. 40 No. 2, 53-65.

Blackman, M.C. and Funder, D.C. (1998), “The effect of information on consensus and accuracy in personality judgment”, Journal of Experimental Social Psychology, Vol. 34 No. 2, pp. 164-181.

Chai, K.H. and Xin, Y. (2006), “The Application of New Product Development Tools in Industry: The Case of Singapore", IEEE Transactions on Engineering Management, Vol. 53 No. 4, pp. 543-554. 
Cooper, R.G. (1993), Winning at New Products: Accelerating the Process from Idea to Launch, Addison-Wesley, USA.

Fern, E.F. (1982), “The Use of Focus Groups for Idea Generation: The Effects of Group Size, Acquaintanceship and Moderator on Response Quantity and Quality”, Journal of Marketing Research, Vol. 19 No. 1, 1-13.

Firat, A.F. and Venkatesh, A. (1995), "Liberatory postmodernism and the reenchantment of consumption,” Journal of Consumer Research, Vol. 22 No. 3, pp. 239-267.

Gardiner, P., and Rothwell, R. (1985), “Tough customers: good designs”, Design Studies, Vol. 6 No. 1, pp.7-17.

Griffin, A., and Hauser, J. R. (1993), "The Voice of the Customer", Marketing Science, Vol. 12 No. 1, pp. 1-27.

Gruner, K.E. and Homburg, C. (2000), "Does Customer Interaction Enhance New Product Success?” Journal of Business Research, Vol. 49 No. 1, pp. 1-14.

Grönroos, C. (2000), Service Management and Marketing: A Customer Relationship Management Approach, Wiley, USA.

Gustafsson, A., Ekdahl, F. and Edvardsson, B. (1999), "Customer Focused Product Development in Practice - A Case Study at Scandinavian Airlines System (SAS)", International Journal of Service Industry Management, Vol. 10 No. 4, pp. 344-358.

Gustafsson, A. and Johnson, M. (2003), Competing in a Service Economy: How to Create a Competitive Advantage Trough Service Development and Innovation, Jossey-Bass, USA.

Humphreys, A. and Grayson, K. (2008), “The Intersecting Roles of Consumer and Producer: A Critical Perspective on Co-production, Co-creation and Prosumption”, Sociology Compass, Vol. 2 No. 3, pp. 963-980.

Imai, M. (1997), Gemba Kaizen, Wiley, USA. 
Jaworski, B.J., Kohli, A.K. and Sahay, A. (2000), "Market-Driven Versus Driving Markets", Journal of the Academy of Marketing Science, Vol. 28 No. 1, pp. 45-54.

Johnson, M.D. (1998), Customer Orientation and Market Action, Prentice Hall, Upper Saddle River, NJ.

Kristensson, P. (2006), "Managing ideas that are unthinkable in advance: A matter of how and where you ask" in Edvardsson, B., Gustafsson, A., Kristensson, P., Magnusson, P. and Matthing J. (Eds.), Involving Customers in New Service Development, Imperial College Press, London, pp. 127-142.

Kristensson, P., Gustafsson, A. and Archer, T. (2004), "Harnessing the Creative Potential among Users" Journal of Product Innovation Management, Vol. 21 No. 1, 4-14.

Krueger, R.A. and Casey, M.A. (2000), Focus groups: A practical guide for applied research (3rd ed.), Thousand Oaks, Sage Publications, USA.

Kvale, S. and Brinkmann, S. (2008), Interviews: Learning the craft of qualitative research interviewing (2nd ed.). Thousand Oaks, USA.

Leonard-Barton, D. (1995), Wellsprings of knowledge: Building and sustaining the sources of innovation, HBS Press: Boston, MA.

Levinthal, D. and March, J.G. (1993), “The myopia of learning”, Strategic Management Journal, Vol. 14 (Winter), pp. 95-112.

Lilien, Gary, L., Morrison, P.D., Searls, K. Sonnack, M. and von Hippel E. (2002), "Performance Assessment of the Lead User Idea-Generation Process for New Product Development", Management Science, Vol. 48 No. 8, pp. 1042-1059.

Lilja, J. and Wiklund, H. (2007). A Two-Dimensional Perspective on Attractive Quality. Total Quality Management \& Business Excellence, 18(6), 667-679.

Lusch, R.F. and Vargo, S.L. (2006), “The Service-Dominant Logic of Marketing: Reactions, Reflections, and Refinements”, Marketing Theory, Vol. 6 No. 3, pp. 281-288. 
Lusch, R.F., Vargo, S.L. and O’Brien, M. (2007), “Competing through service: Insights from service-dominant logic", Journal of Retailing, Vol. 83 No. 1, pp. 5-18.

March, J.G. (1991), “Exploration and exploitation in organizational learning”, Organization Science, Vol. 2 No. 1, pp. 101-123.

Marsh, R.L., Ward, T. and Joshua, L. (1999a), "The inadvertent use of prior knowledge in a generative cognitive task", Memory and Cognition, Vol. 27 No. 1, pp. 94-105.

Marsh, R., Bink, M.L. and Hicks, J.L. (1999b), "Conceptual priming in a generative problemsolving task", Memory and Cognition, Vol. 27 No. 2, pp. 355-363.

Martin, C.R. and Horne, D.A. (1992), "Restructuring towards a service orientation: The strategic challenges", International Journal of Service Industry Management, Vol. 3 No. 1, pp. 25-38.

Moeller, S. (2008) "Customer Integration - A Key to an Implementation Perspective of Service Provision”, Journal of Service Research, Vol. 11 No. 2, pp. 197-210.

Nambisan, S. (2002), “Designing virtual customer environments for new product development: Toward a theory", Academy of Management Review, Vol. 27 No. 3, pp. $392-413$.

Narver, J.C. and Slater, S.F. (1990), "The Effect of a Market Orientation on Business Profitability", Journal of Marketing, Vol. 54 No. 4, 20-35.

Narver, J.C., Slater, S.F. and MacLachlan, D.L. (2004), "Responsive and proactive market orientation and new product success", Journal of Product Innovation Management, Vol. 21 No. 5, pp. 334-347.

Neale, M.R. and Corkindale, D.R. (1998), “Co-developing Products: Involving Customers Earlier and More Deeply", Long Range Planning, Vol. 31 No. 3, pp. 418-425. 
Perkins, D. N. (1988), “The possibility of invention,” in Sternberg, Robert. J. (Ed.) The nature of creativity: Contemporary psychological perspectives, Cambridge University Press, Cambridge, NY, pp. 363-386.

Pitta, D.A., Franzak, F. and Katsanis, L.P. (1996), "Redefining new product development teams: Learning to actualize consumer contributions", Journal of Product and Brand Management, Vol. 5 No. 6, pp. 48-60.

Prahalad, C.K. and Ramaswamy, V. (2000), "Co-opting Customer Competence”, Harvard Business Review, Vol. 78 (January-February), pp. 79-87.

Price, L.L. and Ridgeway, N.M. (1983), “Development of a Scale to Measure Use Innovativeness", in Bagozzi, R.P. and Tybout, A. (Eds.), Advances in Consumer Research, Vol. 10, Association for Consumer Research, Ann Arbor, MI, pp. 679-684.

Rothwell, R. (1976), “Marketing - A success factor in industrial innovation," Management Decision, Vol. 14 No. 1, pp. 43-53.

Rust, R.T., Moorman, C. and Dickson, P.R. (2002) “Getting Return on Quality”, Journal of Marketing, Vol. 66 (October), pp. 7-24.

Sawhney, M. (2006), “Going beyond the Product”, in Vargo, S.L. and Lusch, R.F. (Eds.), The Service-dominant Logic of Marketing, M.E. Sharpe, pp. 365-380.

Schkade, D.A. and Kahneman, D. (1998), "Does living in California make people happy? A focusing illusion in judgments of life satisfaction”, Psychological Science, Vol. 9 No.5, 340-346.

Slater, S.F. and Narver, J.C. (1995), "Market Orientation and the Learning Organization”, Journal of Marketing, Vol. 59 No. 3, pp. 63-74.

Slater, S.F. and Narver, J.C. (1998), “Customer-Led and Market-Oriented: Let's Not Confuse the Two", Strategic Management Journal, Vol. 19 No. 10, pp. 1001-1006.

Toffler, A. (1980), The Third Wave, Bantam, New York. 
Trott, P. (2001), “The Role of Market Research in the Development of Discontinuous New Products", European Journal of Innovation Management, Vol. No. 3, pp. 117-125. Vargo, S.L. (2008), “Customer Integration and Value Creation - Paradigmatic Traps and Perspectives”, Journal of Service Research, Vol. 11 No. 2, pp. 211-215.

Vargo, S.L. and Lusch, R.F. (2004), "Evolving to a New Dominant Logic for Marketing", Journal of Marketing, Vol. 68 No. 1, pp. 1-17.

Verma, R., Anderson, C., Dixon, M., Enz, C., Thompson, G. and Victorino, L. (2008), “Key Elements in Service Innovation: Insights for the Hospitality Industry", Cornell Center for Hospitality Research Managerial Reports, Vol. 8 No. 18.

von Hippel, E. (1988), “The Sources of Innovation”, McKinsey Quarterly, Vol. 1, pp. 72-79. von Hippel, E. (1986), "Lead Users: A Source of Novel Product Concepts”, Management Science, Vol. 32 No. 7, pp. 791-805.

von Hippel, E. (1994), “'Sticky Information’ and the Locus of Problem Solving: Implications for Innovation", Management Science, Vol. 40 No. 4, pp. 429-439.

von Hippel, E. (2005), Democratizing Innovation, MIT Press, Cambridge, MA.

Ward, T.B., (1994), "Structured Imagination: The Role of Category Structure in Exemplar Generation”, Cognitive Psychology, Vol. 27 No. 1, pp. 1-40.

Ward, T.B., (1995), “What's old about new ideas?” in Smith, S.M., Ward, T.B, Finke, R.A. (Eds.), The creative cognition approach, MIT Press, MA, pp. 157-178.

Wernerfelt, B. (1984), “The Resource-Based View of the Firm”, Strategic Management Journal, Vol. 5 No. 2, pp. 171-180.

Wernerfelt, B. (1995), “The Resource-Based View of the Firm: Ten Years After”, Strategic Management Journal, Vol. 16 No. 3, pp. 171-174. 
Xie, C., Bagozzi, R.P. and Troye, S.V. (2007), "Trying to prosume: toward a theory of consumers as co-creators of value", Journal of the Academy of Marketing Science, Vol. 36 No. 1, 109-122.

Zaltman, G. (2003), How Customers Think: Essential Insights into the Mind of the Markets, Boston: Harvard Business School Press, 2003. 


\section{FIGURES AND TABLES}

Table 1: An overview of the sample

\begin{tabular}{|l|c|c|c|c|}
\hline Industry & $\begin{array}{c}\text { No. of } \\
\text { companies }\end{array}$ & $\begin{array}{c}\text { No. of } \\
\text { employees }\end{array}$ & $\begin{array}{c}\text { Turnover } \\
\text { [MSEK] }\end{array}$ & $\begin{array}{c}\text { Profit } \\
\text { margin } \\
{[\%]}\end{array}$ \\
\hline Wood, pulp and paper & 22 & 270 & 829,593 & 3.48 \\
\hline Chemicals & 8 & 235 & 283,966 & 3.1 \\
\hline Plastic products & 9 & 16 & 78,509 & 4.45 \\
\hline Fabricated metal products & 26 & 62 & 82,194 & 2.67 \\
\hline Machinery and equipment & 27 & 133 & 207,494 & 3.78 \\
\hline $\begin{array}{l}\text { Electrical and optical } \\
\text { equipment }\end{array}$ & 16 & 108 & 209,977 & 2.55 \\
\hline Construction & 16 & 330 & 419,287 & 1.7 \\
\hline Real estate & 15 & 224 & 893,939 & 7.67 \\
\hline Construction & 39 & 352 & 280,931 & 2.18 \\
\hline Business services & 17 & 977 & 495,545 & 3.75 \\
\hline
\end{tabular}


Table 2: Results of Study I

\begin{tabular}{|l|c|c|}
\hline & Profit margin & t-values \\
\hline Intercept & -1.42 & -0.975 \\
\hline Firm size & -0.289 & -0.959 \\
\hline Previous profit margin & 0.201 & $5.37 ; \mathrm{p}<0.01$ \\
\hline Use of customer interviews & -0.031 & -0.188 \\
\hline Use of lead users & 0.340 & $2.041 ; \mathrm{p}<0.05$ \\
\hline $\mathrm{R}^{2}(\%)$ & 13.2 & \\
\hline
\end{tabular}


Table 3: Results of Study II

\begin{tabular}{|l|c|c|c|}
\hline & In-depth interviews & Focus Groups & Co-creation \\
\hline No. of ideas & 51 & 136 & 62 \\
\hline No. of participants & 11 & 28 & 11 \\
\hline Ideas per participant & 4.64 & 4.86 & 5.64 \\
\hline Originality $_{\text {All Ideas }}$ & $3.63(\mathrm{~ns})$ & $3.47(\mathrm{p}<0.05)$ & 3.95 \\
\hline Value $_{\text {All Ideas }}$ & $6.12(\mathrm{~ns})$ & 6.03 & 6.03 \\
\hline Originality $_{\text {Best Ideas }}$ & $3.69(\mathrm{p}<0.05)$ & $3.33(\mathrm{p}<0.05)$ & 4.55 \\
\hline Value $_{\text {Best Ideas }}$ & $6.64(\mathrm{~ns})$ & $6.40(\mathrm{~ns})$ & 6.36 \\
\hline
\end{tabular}

Note: For "best ideas", the five ideas with the highest ranks are implied. 
Table 4: A test of originality and customer value for goods-based and service-based ideas

\begin{tabular}{|l|c|c|}
\hline & Goods-based ideas & Service-based ideas \\
\hline No. of ideas & 125 & 38 \\
\hline Originality & 3.69 & $5.48(\mathrm{p}<0.05)$ \\
\hline Value & $6.47(\mathrm{p}<0.01)$ & 5.83 \\
\hline
\end{tabular}

